\title{
Propagation of Dendrobium antennatum Lindl via Seed Culture In Vitro Using Simple Medium: Fertilizer and Complex Organic Based Medium
}

\author{
Julius Dwi Nugroho ${ }^{1 *}$, Agustina Yohana Setyarini Arobaya ${ }^{2}$, Evelyn Anggelina Tanur ${ }^{1}$ \\ 'Silviculture Laboratory, Faculty of Forestry, Papua University, Manokwari, Indonesia \\ ${ }^{2}$ Conservation Laboratory, Faculty of Forestry, Papua University, Manokwari, Indonesia
}

ARTICLE INFO

\section{Article history:}

Received February 10, 2017

Received in revised form September 15, 2018

Accepted January 17, 2019

\section{KEYWORDS:}

Dendrobium antennatum,

Growmore 10-55-10,

coconut water,

spring onion,

seed germination

\begin{abstract}
A New Guinea Orchid, Dendrobium antennatum Lindl urgently needs to conserve. The availability of in vitro germination technique for this orchids is significantly important to present the useful tool for conservation effort. This study aimed to find a simple media that consists of Growmore 10-55-10, a foliar fertilizer and complex organic i.e. coconut water, banana pulp, onion spring extract, and carrot juice. Five in vitro medium for seed germination and four in vitro sub-culture medium for planlet growth were formulated and used in this study. Our findings revealed that seed germination in vitro of Dendrobium antennatum well occured on the medium of Growmore 10-55-10 supplemented with $10 \%$ coconut water (GCw) and of Growmore 10-55-10 supplemented with $50 \mathrm{~g} / \mathrm{l}$ extract spring onion. The seed germination process from sowing the seed to plantlet production ready to transfer to sub-culture medium for further growth took time 140 days. The embryo became pale green at the day 11 on the germination media. It could be used as a tool for detection of viability of the seeds. Both seed germination medium could be used also as sub-culture medium for enhancing the growth of the plantlets but not for multiplication of shoots.
\end{abstract}

\section{Introduction}

Dendrobium antennatum Lindl, locally knows as an antelope orchid (anggrek kelinci) occurs widely in New Guinea region. The species has an economic value aspecially as a parent material in breeding programme to produce new variant of orchids. Nowdays, in its habitat, this orchid species is treatened by the conversion of the forest through the development of the regions. Without any effort this species can be distict, therefore the conservation effort is a must, for example through ex situ conservation.

Naturally, D. Antennatum easialy to produce fruit with abundance of seeds in nature. But like other orchids, it is only a small portion of viable seeds be able to germinate because of its tiny seed. The seed likes these, contains insufficient reserve of nutrients for germination (Teixeira da Silva et al. 2015b).

\footnotetext{
* Corresponding Author

E-mail Address: jd.nugroho2014@gmail.com
}

Therefore, it is needed to develop in vitro technique to germinate the seeds. The availability of in vitro germination technique for orchids is siqnificantly important to present the useful propagation of valuable germplasm and maintaining the genetic heterogeneity inherent in seeds (Teixeira da Silva et al. 2015b). On the other hand, understanding germination process is very urgent since this could provides insight knowledge of this species seed biology that aids in their in vitro propagation (Zeng et al. 2013).

The succes of in vitro propagation methods in orchids depends on many factors. One important factor is the culture medium. To seek the suitable culture medium, the composition of the nutrients and the content of growth regulators in the medium is play important role. The most common basal media used for Dendrobium in vitro propagation is MS and half strenght of MS, while natural supplements often to use, among them are cococut water and banana pulp (Teixeira da Silva et al. 2015a, 2015b). Some studies have used foliar fertilizer based medium such 
as the used of Growmore (Harahap 2014; Inkiwirang et al. 2016) and Hyponex (Nuraini et al. 2011).

However, it is often the present available medium constitute of materials that is expensive and unavailable in local market especially in remote areas. This lets to the difficulty in orchids conservation effort. In a principle, the efficient protocol of tissue culture of any plants is not only of on the suitable culture media but also of on the cheap and on the simple of the protocol. Therefore, the use of alternative materials such as foliar fertilizer and complex organics available locally for formulating the media are need to study.

This study aimed to find a simple ingredient of media that the materials are cheap and easy to find locally but suitable to use for $D$. antenatum seed germination and the plantlet growth. In this research we used Growmore 10-55-10, a foliar fertilizer and complex organik i.e. coconut water, banana pulp, onion spring extract, and carrot juice which are cheap and easily to find in local market for formulating the simple medium.

\section{Materials and Methods}

\subsection{Materials}

Mature fruits (capsules) of Dendrobium antennatum used as seed sources for seed culture in vitro. We used Growmore 10-55-10, a fertilizer, as a source of nutrients which is avalaible and easily found in the local market. Growmore 10-55-10 have chemical contains of ammoniacal nitrogen $8.5 \%$, nitrate nitrogen $0.5 \%$, urea nitrogen $1.0 \%$, available phosphoric acid $\left(\mathrm{P}_{2} \mathrm{O}_{5}\right) 55 \%$, soluble potash $\left(\mathrm{K}_{2} \mathrm{O}\right) 10 \%$, calcium (Ca) $0.05 \%$, magnesium (Mg) $0.10 \%$, sulfur $(\mathrm{S})$ combined $0.20 \%$, boron (B) $0.02 \%$, coper (Co) $0.05 \%$, iron (Fe) $0.1 \%$, manganese $(\mathrm{Mn}) 0.05 \%$, molybdenum (Mo) $0.0005 \%$, and zinc $(\mathrm{Zn})$ 0.05\%. Other materials used for the medium were complex organics i.e coconut water, banana pulp, carot juice, and onion spring (Allium fistolisum) extract.

\subsection{Experimental Design}

\subsubsection{The Germination of $D$. antennatum Seeds on Simple Medium}

Simple medium containing the fertilizer and natural ingredients were used for seeking the media suitable for seed germination and plantlet growth of $D$. antennatum. As comparison, we used Murashige and Skoog (MS) media (Murashige and Skoog 1962) supplemented by coconut water. Experiment for the seed germination was set up in a completely randomized design. There were 5 medium as the treatments i.e. (1) MSCW $=\mathrm{MS}+$ coconut water $10 \%$ + sucrose $20 \mathrm{~g} / \mathrm{l} ;$; (2) GCW $=$ Growmore $1 \mathrm{~g} / \mathrm{l}+$ coconut water $10 \%+$ sucrose $20 \mathrm{~g} / \mathrm{l}$; (3) GCwB $=$ Growmore $1 \mathrm{~g} / \mathrm{l}+$ banana pulp $100 \mathrm{~g} / \mathrm{l}+$ coconut water $10 \%$ + sucrose $20 \mathrm{~g} / \mathrm{l}$; (4) GCwBCr = Growmore $1 \mathrm{~g} / \mathrm{l}+$ banana pulp $100 \mathrm{~g} / \mathrm{l}+$ coconut water $10 \%+$ carrot juice $50 \mathrm{ml}+$ sucrose $20 \mathrm{~g} / \mathrm{l}$; (5) GS = Growmore $1 \mathrm{~g} / \mathrm{l}+$ spring onion extract $50 \mathrm{~g} / \mathrm{l}+$ sucrose $20 \mathrm{~g} / \mathrm{l}$. All treatments were replicated in 5 culture bottles. The germination proccess was also monitored through the sowing of the seeds on the sterile filter paper wetted with sterile liquid medium of GCW (without sugar and agar) in petridish.

Percent germination $(G)$ were determined based on the number of culture bottles showing success in germintaion. While the Mean Germination Time (MGT) was measured using the formula MGT = $\left\{\left(\Sigma\left(t_{i} n_{i}\right) /\left(\Sigma n_{i}\right)\right\}\right.$, where $\mathrm{t}$ is the day needed for the seed to germinate, determined from the day of seed planting ( 0$)$ and $n=$ number of culture bottles containing seeds that were being able to germinate in the end of the experiment (Modified from Hartman et al. 2002). Plantlets resulted from the germination were also classified their quality through the color of the planlets resulted in the end of the experiment, i.e. dark green $(+++)$, green $(++)$, and yellowish green $(+)$.

\subsubsection{The Growth of $D$. antenatum Plantlets in Sub-Culture}

The effects of sub-culture medium to the growth of the planlets were performed in a completely randomized design. After 5 month planting in the germination medium, the plantlets, then tranferred to sub-culture medium. The nutrient composition of sub-culture medium were the same as the medium applied in the seed germination test. However we eliminated the medium $\mathrm{GCWBCr}$ that gave the least unsastified result of seed germination. Therefore we have only 4 treatments which each was replicated 7 times ( 7 culture bottles). The variables measured were (1) the height of the plantlets ( $\mathrm{mm}$ ) which was measured from the base of the stem to the tip of the leave; (2) the number of the shoots ( $\mathrm{n})$; (3) the number of the roots $(\mathrm{n}) ;(4)$ the lenght of the roots $(\mathrm{mm})$ was measured based on the longest root. 


\subsubsection{Capsule Sterilization, Media Preparation, and Culture Conditions}

Uncracked and mature capsules of $D$. Antennatum from the field was harvested and transport to the laboratory. The capsules were cleaned with detergent solution and rinse with sterile water. Then the capsules were put in the transfer table of the laminar flow and they soaked in alcohol 70\% in 5 minute and flamed by passed them on bunsen burner, repeatedly three times. The capsule put in the sterile petridish, dissected the capsules longintudinally, and release the seeds using sterile spatula. The released seeds were spreaded over the surface of the medium. We used one capsule for all five treatments (five culture bottles) in each replicates. Thus totally, we used 5 capsules for all experiment units.

Germination medium were prepared by blended $100 \mathrm{~g}$ banana, taken out carrot juice for $50 \mathrm{ml}$ using juicer and blended $1 \mathrm{~g}$ of basal portion of spring onion then taken out its juice. The complex organics were mixed throughly with the fertilizer for making 11 medium. The preparation of sub-culture medium were similar to the germination medium.

All the medium were adjusted to the $\mathrm{pH} 5.8$ before autoclaving and the cultures were maintained in culture room at $26 \pm 1^{\circ} \mathrm{C}$, with the daily light provided by cool-white fluorescent tubes for $10 \mathrm{~h}$.

\subsection{Data Analysis}

The data were analysed statistically. The data of percent germination and the rate of germination were analysed through descriptive statistic i.e means and Standart Deviation (SD), while the data of plantlet growth in sub-culture medium were analysed using analysis of variance (anova). Then the mean values were compared with Least Square Difference (LSD) at the level of signivicance $\alpha=0.05$. Statistical procedures were performed using the $\mathrm{R}$ software version 2.10.0 (R Develpment Core Team 2010).

\section{Results}

Seed germination is defined as the emergence of radicle through seed coat involving some steps, begins with water imbibition and enzime syntensis followed by embryo growth which develop to protocorm, emergence of the radical, and finally the production of plantlets (Figure 1). Germination test on filter paper wetted with liquid medium of GCW

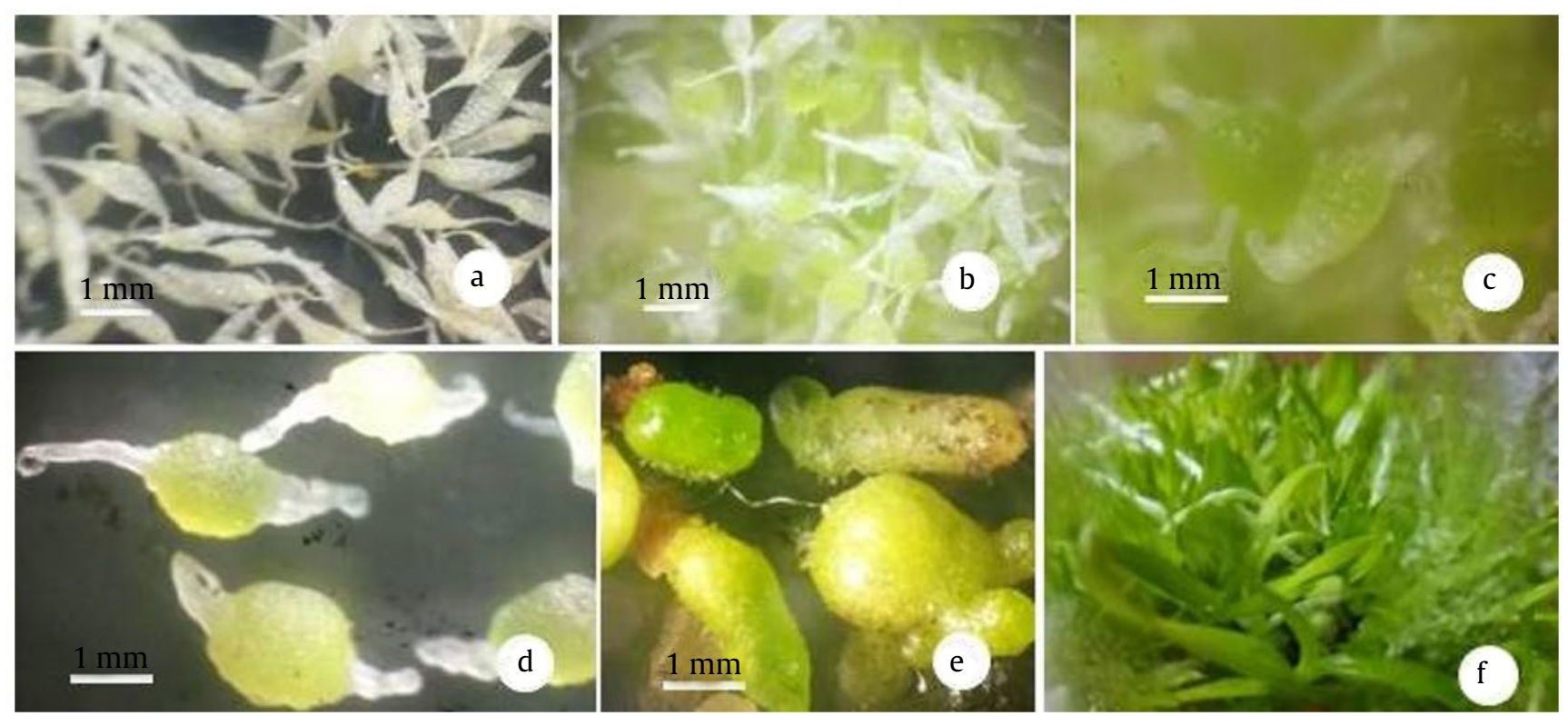

Figure 1. Steps of germination process of Dendrobium antennatum on filter paper supplied with liquid medium of GCW (without sugar and agar). (a) seeds of $D$. antennatum in the day 0 appeared yellowish white, changed the color becoming pale green (b), in the day 11, following the enlargement of the embryos (b-d), further developed to form protocorm (e), and finnally the production of plantlets on the day 140 (f) 
without sugar and agar showed that the process of the germination until achieving the plantlet production needed 140 days from the sowing.

Asymbiotic in vitro seed germination test of $D$. antennatum on five medium showed that the seed germination well occured only in three medium (100\% germination in MSCw, GCw, and GS) with the mean germination rate (MGR) equally similar i.e. $34.4 \pm 7.20$ days in GS, $37.8 \pm 8.80$ days in $\mathrm{MScW}$, and $39.80 \pm 10.80$ days in GCW (Table 1 ). Although based on the percent germination $(G)$ and MGR, we found three best medium for germination, in fact the quality of plantlets produced using those medium were markedly different. Among the three, medium GCW and GS gave equaly good quality of plantlet production as showed by their collor of dark green $(+++)$. In contrast with medium MSCw, GCwB, and GCwBCr showed pale color (++ and + ) or yellowish green (Figure 2 ).

The growth of the planlets for 100 days in subculture medium is presented in Table 2 . Based on the analysis of variance, the treatments gave a significantly different effect to all variables measured, except to the number of shoots. Further analysis to mean value comparation analysis using LSD at the level of $p>0.05$, it indicated that plantlets sub-cultured on medium of $\mathrm{GCW}$ and GS gave the best growth in term of height, root number and root lenght of the plantlets. The height, root number, and root lenght of the planlets respectively $58.0 \pm 5.0 \mathrm{~mm}, 5.7 \pm 1.0$ roots, $29.3 \pm 2.0 \mathrm{~mm}$ on GCW medium and $51.3 \pm 9.1 \mathrm{~mm}, 5.9 \pm 2.1$ roots, and
$33.3 \pm 7.8 \mathrm{~mm}$. However all treatments of sub-culture medium did not affected in the production of shoots.

\section{Discussion}

According to Hartman et al. (2002), there are three factors must be fulfilled for seed germination. Firstly, the seed must be viable. It means that the embryo must be alive and capable to germinate; secondly, the seed must be subjected to the proper conditions of environments for germination and thirdly any primary dormancy condition present must be removed. In our study, we did not conducted seed viability test, therefore we did not know the percentage of the viable seed. The

Table 1. Results of in vitro germination test of $D$. antennatum on medium MSCW (MS + coconut water $10 \%+$ sucrose $20 \mathrm{~g} / \mathrm{l}$ ), GCW (Growmore $1 \mathrm{~g} / \mathrm{l}+$ coconut water 10\% + sucrose $20 \mathrm{~g} / \mathrm{l}$ ), GCwB (Growmore 1 $\mathrm{g} / \mathrm{l}+$ banana pulp $100 \mathrm{~g} / \mathrm{l}+$ coconut water $10 \%+$ sucrose $20 \mathrm{~g} / \mathrm{l}$ ), GCwBCr (Growmore $1 \mathrm{~g} / \mathrm{l}+$ banana $100 \mathrm{~g} / \mathrm{l}+$ coconut water $10 \%+$ carrot juice $50 \mathrm{ml}+$ sucrose $20 \mathrm{~g} / \mathrm{l}$ ), GS (Growmore $1 \mathrm{~g} / \mathrm{l}+$ spring onion extract $50 \mathrm{~g} / \mathrm{l}+$ sucrose $20 \mathrm{~g} / \mathrm{l})$. Percent germination $(\mathrm{G})$, the time needed to germinate (MGR) and the plantlet quality (dark green $=+++$, green $=++$, and yellowish green $=+$ )

\begin{tabular}{lclc}
\hline Treatments/medium & G $(\%)$ & MGR (days) & Plantlet quality \\
\hline MSCw & 100 & $37.8(8.80)$ & ++ \\
GCw & 100 & $39.80(10.80)$ & +++ \\
GCwB & 30 & $93.67(2.33)$ & + \\
GCwBCr & 20 & $96.00(48.00)$ & + \\
GS & 100 & $34.4(7.20)$ & +++ \\
\hline
\end{tabular}

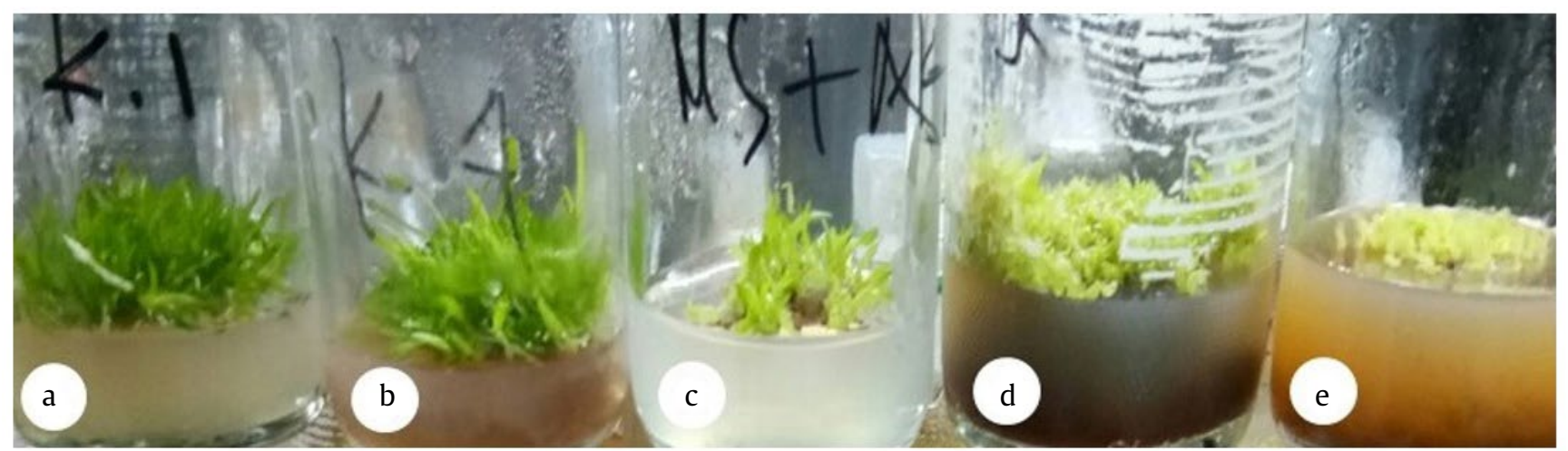

Figure 2. D. antennatum planlets, a result of seed germination, ready to transfer into sub-culture medium, at 140 days after sowing. (a) the plantlets growing on GCw (Growmore $1 \mathrm{~g} / \mathrm{l}+$ coconut water $10 \%+$ sucrose $20 \mathrm{~g} / \mathrm{l}$ ) medium and (b) on GS (Growmore $1 \mathrm{~g} / \mathrm{l}+$ spring onion extract $50 \mathrm{~g} / \mathrm{l}+$ sucrose $20 \mathrm{~g} / \mathrm{l}$ ) medium showed healthy with dark green color of leave, while (c) on MSCw (MS + coconut water 10\% + sucrose $20 \mathrm{~g} / \mathrm{l}$ ); GCw (Growmore $1 \mathrm{~g} / \mathrm{L}+$ coconut water $10 \%+$ sucrose $20 \mathrm{~g} / \mathrm{l})$ medium showed pale green of leave and both, (d) on GCwB (Growmore $1 \mathrm{~g} / \mathrm{l}$ + banana pulp $100 \mathrm{~g} / \mathrm{l}+$ coconut water 10\% + sucrose $20 \mathrm{~g} / \mathrm{l}$ ), and (e) GCwBCr (Growmore $1 \mathrm{~g} / \mathrm{l}$ + banana $100 \mathrm{~g} / \mathrm{l}$ + coconut water $10 \%$ + carrot juice $50 \mathrm{ml}$ + sucrose $20 \mathrm{~g} / \mathrm{l}$ ) showed yellowish green color of leave 
Table 2. The growth of D. antennatum plantlets in the sub-culture medium of MSCW (MS + coconut water $10 \%+$ sucrose 20 $\mathrm{g} / \mathrm{l}$ ), GCw (Growmore $1 \mathrm{~g} / \mathrm{l}+$ coconut water $10 \%$ + sucrose $20 \mathrm{~g} / \mathrm{l}$ ); GCwB (Growmore $1 \mathrm{~g} / \mathrm{l}+$ banana pulp $100 \mathrm{~g} / \mathrm{l}+$ coconut water $10 \%+$ sucrose $20 \mathrm{~g} / \mathrm{l}$ ); GS (Growmore $1 \mathrm{~g} / \mathrm{l}+$ spring onion extract $50 \mathrm{~g} / \mathrm{l}+$ sucrose $20 \mathrm{~g} / \mathrm{l}$ ) 100 days after transfering into the sub-culture medium

\begin{tabular}{lcccc}
\hline Medium & \multicolumn{5}{c}{ Growth variables } \\
\cline { 2 - 5 } treatments & Height of plantlets (mm) & Root number of plantlets (n) & Root lenght of plantlets $(\mathrm{mm})$ & Number of shoots \\
\hline MSCw & $20.3(10.1) \mathrm{b}^{*}$ & $1.8(0.9) \mathrm{b}$ & $6.3(2.9) \mathrm{b}$ & $1.4(0.5) \mathrm{a}$ \\
GCw & $58.0(5.0) \mathrm{a}$ & $5.7(1.0) \mathrm{a}$ & $29.3(2.0) \mathrm{a}$ & $1.3(0.43) \mathrm{a}$ \\
GCwB & $27.1(5.9) \mathrm{b}$ & $2.0(0.9) \mathrm{b}$ & $5.6(2.9) \mathrm{b}$ & $1.0(0.0) \mathrm{a}$ \\
GS & $51.3(9.1) \mathrm{a}$ & $5.9(2.1) \mathrm{a}$ & $33.3(7.8) \mathrm{a}$ & $1.1(0.2) \mathrm{a}$ \\
\hline
\end{tabular}

${ }^{*}$ The letters in each row after mean values (SD) indicates not significantly different based on LSD test at $\mathrm{p}>0.05$

germination test was based on the number of cultures showing the seed planted be able to germinate. The seeds of various Dendrobium included $D$. antennatum did not showed the presence of seed dormancy since various studies pointed out that in vitro asymbiotic seeds of these species were success to germinate without applying any seed pre-treatments (Fu et al. 2014; Teixeira da Silva et al. 2015a, 2015b; Utamy and Haryanto 2016). The germination test in this study only intended to evaluate the most important enviromental factor that was the composition of the medium suitable for germination and plantlet growth.

The process of $D$. antennatum germination is similar to the result of Utami and Haryanto (2016) observation with differ only on the lenght period of each steps of germination. The viable seeds began to enlarge and developed gradualy with the change of their color. It was noticed that the seeds proceeded these steps appeared pale green. This change of the seed color be used as a detection that the seed is viable. In the contrary, the seeds that remained yellowish white are not viable and this could be detected on the day 11 after sowing. Colorization of orchid seeds following the staining procedure using triphenyl tetrazolium chloride (TTC), fluorescein diacetat (FDA), and acid fuchsin (AC) are frequently used. Vujanovic et al. (2000) proposed alternative in vitro bioassay germination test using Fusarium isolate from the protocorm of Cypripedium reginae that brought about similar result to that of standar chemical procedure.

The seeds of $D$. antennatum germinated well on the MS suplemented with $10 \%$ coconut water (MSCw) medium, which was equal to Growmore 10-55-10 suplemented with $10 \%$ coconut water (GCW) medium, and Growmore 10-55-10 suplemented with $50 \mathrm{~g} / \mathrm{l}$ extract spring union (GS) medium in term of percent germination $(G)$ and mean germination rate (MGR). However based on the quality of the planlet produced, only GCW and GS medium could be recommended as
D. antennatum seed germination medium in vitro. In fact the initiation of seed germination, and protocorm development to planlets are vary and influenced by the medium employed (Robinson et al. 2009; Dutta et al. 2011). As comparison, Utami and Haryanto (2016) used MS medium with the combination of $2 \mathrm{~g} / \mathrm{l}$ peptone and $20 \%$ coconut water resulted in the highest percentage of total seed germination of $D$. antenatum (92.2\%). In addition Robinson et al. (2009) found that in case of Dendrobium aqueum Lindl.

The growth of $D$. antennatum planlets responsed positively on the sub-culture medium used, especially GCW and GS medium. The two medium facilitated for best plantlet growth comparing to the other medium in all growth variables measured with the exception of shoot number. It seems that the use of coconut water and spring onion extract might induce the height and root growth but not shoot proliferation.

Some researchers have used foliar fertilize for formulating in vitro orchid medium. The use of Growmore 40-20-20 in the study of Harahap (2014) affected differently as comparing with the use of Growmore 10-55-10 in this study. Growmore 40-2020 based in vitro medium clearly affected the shoots proliferasi better due to the content of nitrogen that is responsible to the higher shoot growth.

Natural complex organic such as coconut water is very common to use as supplement in culture in vitro of Dendrobium species (Teixeira da Silva et al. 2015a). Coconut water is a liquid endosperm with have unique chemical compotition including sugars, vitamin, minerals, lipids, amino acid, phenolics, and phytohormones. Auxin, 1,3-Diphenylurea and cytokinin are the fitohormones can be traced. This supplement also have antioxidant activity (Young et al. 2009; Santos et al. 2013). The use of coconut water as supplement in vitro medium including in seed germination medium is usually at the concentration of $10-20 \%$ (Teixeira da Silva et al. 2015a; Utami and Haryanto 2016). Furthermore, 
Harahap (2014) pointed out that in the low concentration of coconut water $(<10 \%)$ resulted in pale green color of shoots, while in the high concentration of coconut water (>15\%), the suplement gave inverse effect, by which the shoot became stunted and died.

On the other hand, the use of onion spring is not common, but based on the findings of this study, this supplement is prospective to be used for germination and planlet growth media of $D$. antennatum. In this study revealed that the use of this supplement was as effective as the use of coconut water for induce the seed germination as well as the plantlet growth. The seed planted on this medium germinated well and produced good quality plantlets. The plantlets growing on this medium produced the highest number of roots and root lenght, likely because of phytohormon content in it. Likes other onion, this supplement is rich in organic acids, sugars, phenols, and have antioxidant activity (Liguori et al. 2017; Aslam et al. 2017).

Overall, this study revealed that the medium of Growmore 10-55-10 supplemented with $10 \%$ coconut water (GCW) and Growmore 10-55-10 supplemented with $50 \mathrm{~g} / \mathrm{l}$ extract spring onion could be use for seed germination medium and planlet growth of $D$. antennatum but not for multiplication medium.

\section{Acknowledgements}

The authors are thanksful to Claudya Novia Karubuy, the student of Papua University, who helped with the culture in vitro work in the Silviculture Laboratorium of Papua University. This research were supported by the laboratorium through the utilization all the fasilities during the experiments.

\section{References}

Aslam Z et al. 2017. Antioxidant activity, anti-imflammatory activities, anti cancer and chemical composition of spring onion (Allium Fistolisum) extracts. RJPBCS 8:1880-1890.

Duta S et al. 2011. In vitro multiplication and protocorm development of Dendrobium aphyllum (Roxb.) CEC Fisher. Assam University Journal of Science and Technology: Biological and Environmental Sciences 7:57-62.
Fu C et al. 2014. Study on hybridation and aseptic seeding as well as rapid propagation of Dendrobium officinale and Dendrobium aduncum. Medicinal Plant 5:55-58.

Harahap F. 2014. The growth of orchids (Dendrobium sp.) in vitro with coconut water in different medium. In: Proceeding of the First International Seminar on Trends in Sciences and Science Education. Medan: Universitas Negeri Medan. pp. 46-53.

Hartman HT et al. 2002. Plant Propagation: Principles and Practices. $7^{\text {th }}$ ed. New Jersey: Prentice-Hall International.

Inkiwirang AEB et al. 2016. Subsitusi media murashige dan skoog/MS dengan air kelapa dan pupuk daun majemuk pada pertumbuhan anggrek Dendrobium Secara in vitro. Jurnal Bioslogos 6:15-19.

Liguori L et al. 2017. Chemical composition and antioxidant properties of five white onion (Allium cepa L.) Landraces. Journal of Food Quality 2017:1-9. DOI: $10.1155 / 2017 / 6873651$

Nuraini et al. 2011. Growth and development of Dendrobium spectabile orchid protocorm to various combination alternative media in vitro. In: Prosiding Seminar Nasional Florikultur 2011. Cianjur: Balai Penelitian Tanaman Hias. pp. 81-90.

R Development Core Team. 2010. R: A Language and Environment for Statistical Computing. Vienna: $\mathrm{R}$ Foundation for Statistical Computing.

Utami ESW, Haryanto S. 2016. The effect of organic nutrient and growth regulators on seed germination, Embryo and shoot development of Dendrobium antennatum by in vitro. Biosaintifika: Journal of Biology Education 8:165-171.

Robinson JP et al. 2009. In vitro seed germinatiom and protocorn development of Dendrobium aqueum Lindl. A rare orchid species from eastern ghats of Tamil Nadu. Botany Reseach International 2:99-102.

Santos JLA et al. 2013. Evaluation of chemical constituents and antioxidant activity of coconut water (Cocus nucifera L.) and caffeic acid in cell culture. An Acad Bras Cienc 85:1235-1246. DOI:10.1590/0001-37652013105312

Teixeira da Silva JA et al. 2015a. Dendrobium micropropagation: a review. Plant Cell Rep 34:671-704.

Teixeira da Silva JA et al. 2015b. Asymbiotic in vitro seed propagation of Dendrobium. Plant Cell Rep 34:1685-1706.

Vujanovic V et al. 2000. Viability testting of orchid seed and the promotion of colorization and germination. Annals of Botany 86:79-86.

Young JWH et al. 2009. The chemical composition and biological properties of coconut (Cocos nucifera L.) water. Molecules 14:5144-5164.

Zeng S et al. 2013. Seed biology and in vitro seed germination of Cyperidium. Critcal Review in Biotecnology 34:358-371. 